\title{
IMPROVING THE RECTIFICATION OF OPTICAL DEVICES WITH LASER POINTERS
}

\author{
Vojkan M. Radonjića , Branko V. Resimić \\ Serbian Armed Forces, Land Army, \\ Technical Overhauling Institute Čačak, Čačak, Republic of Serbia, \\ a e-mail: vojkan.r69@gmail.com, \\ ORCID iD: \\ b e-mail: resimicbranko@gmail.com, \\ ORCID iD: (i)http://orcid.org/0000-0002-8154-1946
}

http://dx.doi.org/10.5937/vojtehg65-13202

FIELD: Logistics, Maintenance of Technical Means

ARTICLE TYPE: Professional Paper

ARTICLE LANGUAGE: English

\section{Summary:}

This paper is based on the observations of prescribed actions during the maintenance of artillery weapons and immediately prior to the execution of combat firing. Adjusting the parallelism of the axes of the optical devices and the axis of the artillery barrel directly affects shooting accuracy.

With a new method of parallel axes alignment, based on the use of laser pointers, the axis parallelism deviation is reduced to a minimum, which improves the precision of artillery firing. Reliable, easier and faster check of the axes parallelism is enabled as well as axes alignment with the artillery barrel axis.

Keywords: rectification, optical axes, laser pointer.

\section{Introduction}

A new method for checking the parallelism of the axes ${ }^{1}$ of optical devices and the axis of the field artillery weapon $\mathrm{H}-122 \mathrm{~mm}$ D30 (J) was applied in the study. Shooting from this weapon is realized using the following optical sight devices:

- the optical sight ON-122-M78, intended for direct shooting at targets up to a distance of 2000 meters,

- panoramic sight (panorama) P-M78, indirect target shooting to a distance of 16,000 meters.

${ }^{1}$ Checking the parallelism of the axes of optical devices and the artillery weapon barrel axis as well as their alignment (cancellation of deviations in parallel) is called rectification. 


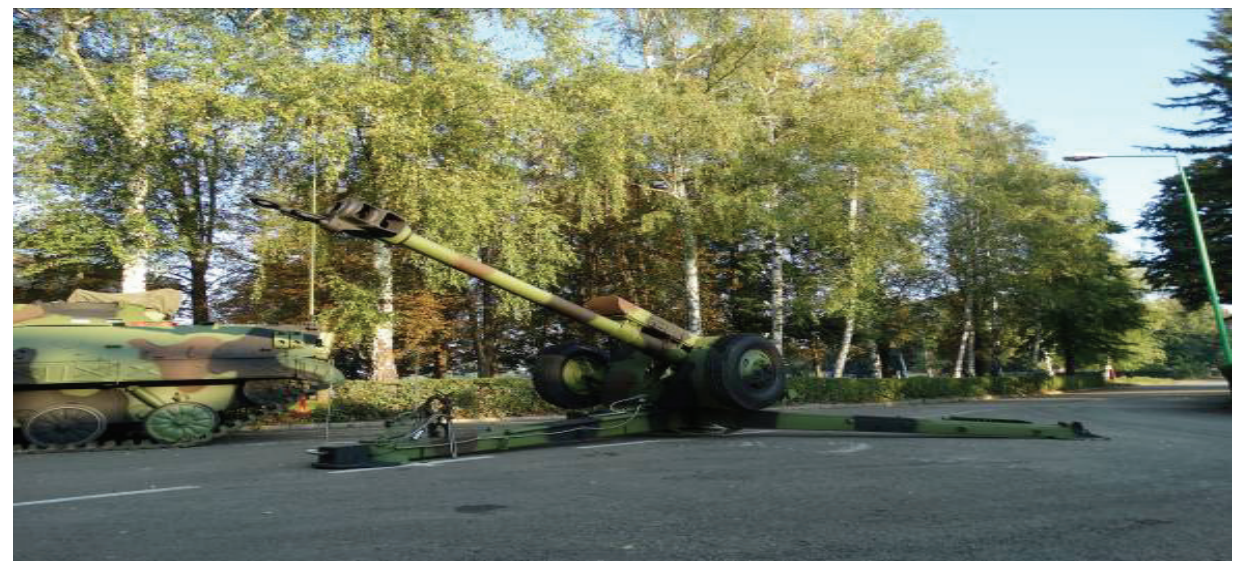

Figure 1 - Field weapon - 122mm howitzer D30

Puс. 1 - Изображение орудия сухопутной артиллерии Гаубица 122мм Дзо Слика 1 - Приказ земаљског оруђа хаубица 122 мм ДЗо

Sighting devices, regardless of their precise adjustment in production, must be checked and adjusted during use. These devices stop being adjusted during use due to wear and tear of moving parts, shocks during shooting and transport, which causes deviation from the axis parallelism and increases the error in weapon accuracy regarding distance and direction.

The aim of the research is the implementation of a new method for checking and adjusting optical axes and the barrel axis, based on the precision of a laser beam emitted by a laser pointer. In this way, the deviation of axes from the parallel is reduced to the minimum value, or zero.

The existing method of checking axes parallelism, on the basis of which further adjustments are made ${ }^{2}$, is directly dependent on the gunner, which leads to different types of errors. One of them is parallax which occurs due to aiming through the barrel bore and the crosshair on the muzzle brake. Also, the existing method is also dependent on the hair/fiber thickness, from which the crosshair is made and mounted on the muzzle brake. It is used for aiming at distant targets and / or at a rectification board. It is clear that the existing method is dependent on human abilities so it does not provide complete reliability due to subjective errors.

According to technical documentation, checking the parallelism of the optical sighting axis with the barrel axis is always performed after mounting the optical sight (OS) on the weapon. Considering the high perio-

${ }^{2}$ Under further adjustment, it is understood that the axes of the optical devices are aligned with the axis of the weapon barrel. 
dicity of repeating paralellism tests, it is necessary to facilitate and accelerate the method. This is enabled by the proposed method of checking axes parallelism using a laser beam (pointer), which makes the method fully reliable.

\section{Existing method of checking axis parallelism according to technical documentation}

Checking axes parallelism means checking the parallel of the three axes (Državni sekretarijat sa narodnu odbranu, Tehnička uprava, 1969):

- optical sight axis,

- optical panoramic sight axis,

- H-122mm D-30 barrel axis.

The goal is that there is no deviation from the parallelism of the imaginary axes of the optical devices and the weapon barrel. In this way, ideal conditions are provided, enabling the accuracy of the sighting devices and the weapon accuracy.

The weapon is placed in a combat position on a flat and hard surface. The barrel is brought into a horizontal position by means of a tilt mechanism, and in the direction towards the rectification board or a remote target.

\section{Checking and adjusting the parallelism of the panoramic sight axis with the barrel axis}

Checking the parallelism of the P-M78 panoramic sight axis and the axis of the weapon barrel, as well as the adjustment of the axis to "ideal" parallelism is performed in two ways:

- using a selected target point at a distance of $1000 \mathrm{~m}$,

- using a rectification board at a distance of $50 \mathrm{~m}$ from the barrel muzzle.

At the muzzle brake, a hair from the crosshair ${ }^{3}$ is tightened into the existing notches ${ }^{4}$. An aiming point is selected at a distance of $1000 \mathrm{~m}$ from the muzzle (Figure 2). The firing mechanism parts are disassembled

${ }^{3}$ Hair of the crosshair - it is made of a fiber of certain thickness. In the tool kit, there is a fiber of about $2 \mathrm{~mm}$ in thickness, red, so that it can be easily visible at aiming at a target or at a cross on the rectification board.

${ }^{4}$ The notches on the muzzle (gas brake) are embeded in the production after the weapon is shot. 
from the breechblock. Aiming through the opening for the firing mechanism probe tip over the crosshair on the muzzle brake, the gunner locks the weapon barrel at a chosen target point. The barrel is moved using a gun laying mechanism. Aiming through the panoramic sight, the gunner adjusts the device until the crosshair of the panoramic sight overlaps with the chosen target and the indices are in the "0" position.

If there is no suitable target point in the vicinity and if visibility is limited, checking the parallelism of the optical axis of the panoramic sight with the barrel axis is done using a rectification board (Figure 3 ). The board is placed at a distance of $50 \mathrm{~m}$ from the howitzer muzzle, vertically and perpendicularly to the barrel axis.

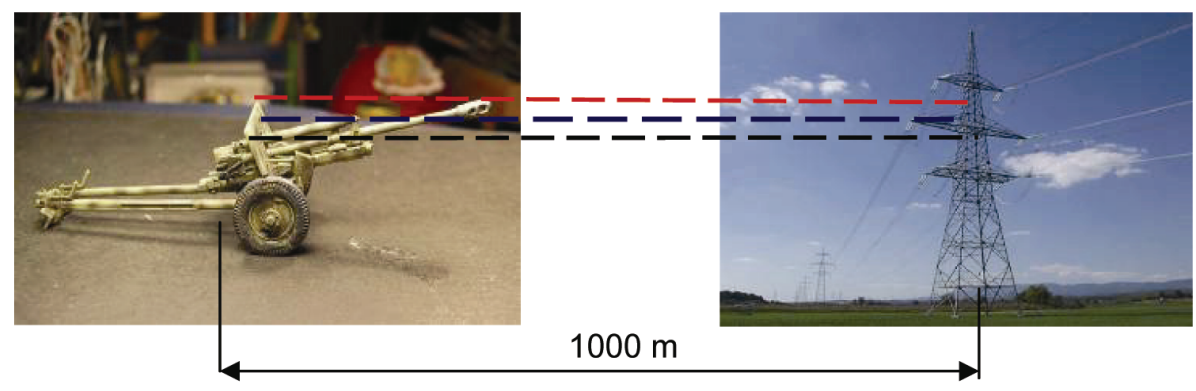

Figure 2 - The process of rectification to the remote selected target Puc. 2 - Метод спрямления траектории при наведении по выбранной дальней цели Слика 2 - Поступак ректификације на удаљени изабрани циљ

As seen in Figure 3, there are three crosses on the board ${ }^{5}$, whose layout and distance corresponds to the position of the optical devices (panoramic sight and optical sight, red and blue cross, respectively) and the axis of the weapon (black cross) in the 3D space.

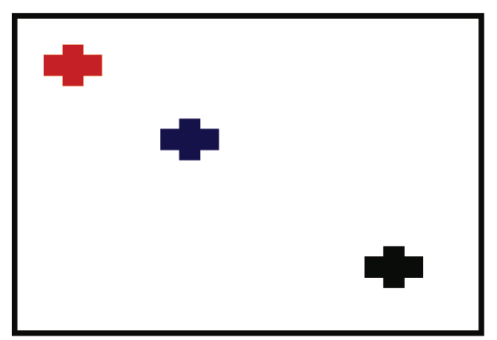

Figure 3- $\mathrm{H}-122 \mathrm{~mm}$ howitzer D30 rectification board

Puс. 3 - Бортовой баллистический вычислитель X-122 мм гаубицы Д30

Слика 3 - Табла за ректифрикацију хаубице X-122 мм Д30

${ }^{5}$ Crosses on the rectification board are referred to as aiming points. 
The parallelism is checked in the following manner: aiming is performed through the bore axis (i.e.hairs of the crosshair) which is thus aligned with the crosss on the right side of the rectification board (Figure 4). The panoramic sight and the optical sight are used for aiming at the crosses on the left side of the rectification board. If the axes of the optical devices deviate from the centres of the crosses on the rectification board, their adjustment is necessary. In this way, the axes of the optical devices are brought into the center of the corresponding cross on the rectification board, which corresponds to the indices on the devices in the "0" position.

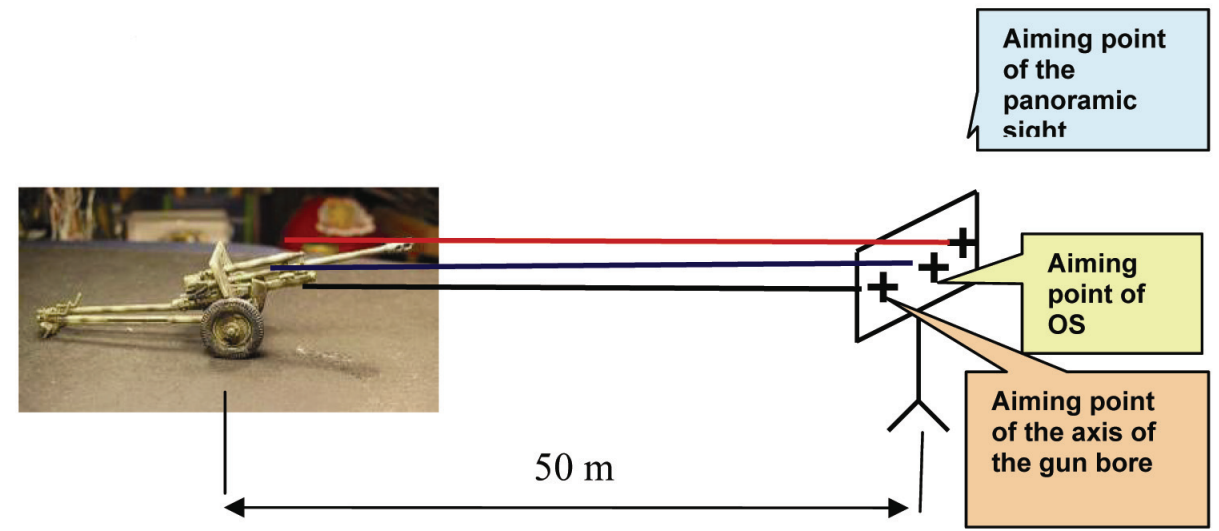

Figure 4 - The process of rectification with a rectification board

Puc. 4 - Метод спрямления прицела с бортовым баллистическим вычислителем Слика 4 - Поступак ректификације са таблом за ректификацију

The technical documentation requires that such rectification be realized by 2 mechanics. The first one aims via the crosshair, aligns the bore axis with the chosen target or the cross on the rectification board and constantly controls the muzzle position. The other mechanic then adjusts the axes of the optical devices with the target or the crosses on the rectification board.

Permissible deviation, when taking the maximum firing distance with the panoramic sight, is 0-00.5 thousandths per direction (Savezni sekretarijat za narodnu odbranu, Tehnička uprava, 1987). 


\section{Checking and adjusting the OS axis parallelism with the barrel axis}

The preparatory actions for the procedure for checking and adjusting the parallelism of the ON-122-M78 OS axis and the barrel axis are the same as the previously explained procedure for the panoramic sight. For the correct operation of the OS, it is necessary that its optical axis be parallel with the bore axis both in the vertical and the horizontal plane. Checking the parallelism of the OS axis and the bore axis is done at a minimum distance of $1000 \mathrm{~m}$ or using a rectification board at a distance of $50 \mathrm{~m}$ from the muzzle.

In the same way as with the panoramic sight (Figure 2), a target is aimed at a minimum distance of $1000 \mathrm{~m}$, using a crosshair. Then, aiming through the OS eyepiece, the gunner determines the position of the top of the arrow in relation to the selected target point. If the OS is correct and properly set, then the top of the arrow will overlap with the remote selected point, and the horizontal line of the crosshair passes through the zero position of the distance scales. If this is not the case, it is necessary to carry out the OS adjustment.

When checking the parallelism of the $\mathrm{ON}$ axis with the bore axis using the rectification board (Fig. 4), the procedure for checking parallelism in the panoramic sight is repeated, and the allowed deviation is 0-01.5 thousandths per direction (Savezni sekretarijat za narodnu odbranu, Tehnička uprava, 1987).

\section{Problems in the rectification procedure according to technical documentation}

When implementing the described methods for checking the parallelism of the optical axes of the panoramic sight and the OS with the barrel axis, we face some problems that cause the measurement uncertainty of the method. Measurement uncertainty depends on the person's ability to precisely determine a target point and aim at it. In this way, a measurement error directly affects the accuracy of the optical devices and, indirectly, the accuracy of the weapon, and the method itself contains measurement uncertainty. 


\section{A procedure of aiming using the barrel axis}

The considered method of checking and adjusting axes parallelism is prescribed by technical documentation. In the realization of the method for checking the axes parallelism, the crosshair is used to aim through the bore at a distant target or at the right cross on the rectification board. The success of aiming using the crosshair depends on the ability of the human eye to perform precise targeting, as well as on the thickness of the hair/fiber with which the target is aimed at. In the weapon STA ${ }^{6}$ kit, there is a factory-standardised fiber which is placed on a gas brake and by which a target is aimed. Therefore, an error is inevitable since the success of the method depends on the human capability to perform the necessary aiming at the remote target or at the cross on the rectification board.

The effect of the thickness of the hair on the precise aiming is considered, assuming that the man has sufficient visual abilities to use a 0,5-2 $\mathrm{mm}$ thick fiber over the bore axis to aim at the right cross on the rectification board and the distant target. An example is given in Figure 5.

The rectification board is placed at a distance of 50 meters from the weapon muzzle. Three $10 \mathrm{~mm}$ thick crosses are drawn on the board, for each of the axes of the optical devices and the weapon bore axis (as it corresponds to their position in the space).

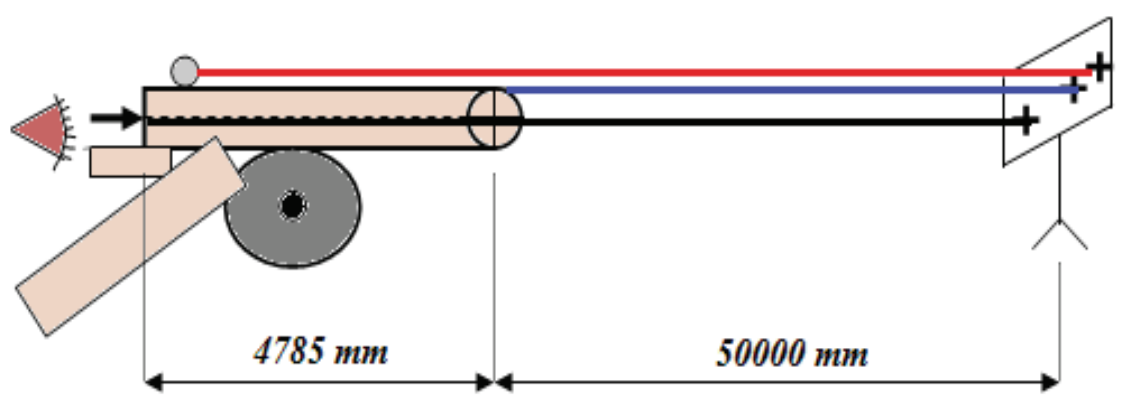

Figure 5 - The process of rectification using the rectification board

Pис. 5 - Метод спрямления наведения с помощью бортового баллистического вычислителя

Слика 5 - Поступак ректификације помоћу табле за ректификацију

To see how the thickness of the fiber affects the correct check of the axes parallelism, the fiber (hair of the crosshair) projection on the rectification board will be calculated. The projection of the fiber is the

${ }^{6}$ STA - Abbreviation of spare tools and accessories 
shape and size of the fiber which the human eye sees on the rectification board when aiming using the crosshair. From the theorem on the similarity of triangles, it follows that (Kalezić, 2010):

$$
\begin{gathered}
L_{C}: d_{K}=L_{U}: x, \\
L_{U}=L_{C}+L_{T} .
\end{gathered}
$$

where:

$\boldsymbol{L}_{C}$ - weapon bore length,

$d_{K}$ - the thickness of the aiming fiber,

$\boldsymbol{L}_{T}$-distance of the board from the weapon muzzle, and

$\boldsymbol{x}$ - projection of the fiber on the rectification board.

Using formula (1) gives the following: $4785: 0.5=54785: x$, where:

$$
x=\frac{54785 \times 0.5}{4785} \Rightarrow x=5.72 \mathrm{~mm} \text {. }
$$

It is concluded that the projection of the $0,5 \mathrm{~mm}$ thich fiber on the rectification board located at a distance of $50 \mathrm{~mm}$ is $5,72 \mathrm{~mm}^{7}$. This means that the crosshair on the gas brake has a projection on the rectification board as in Figure 6.

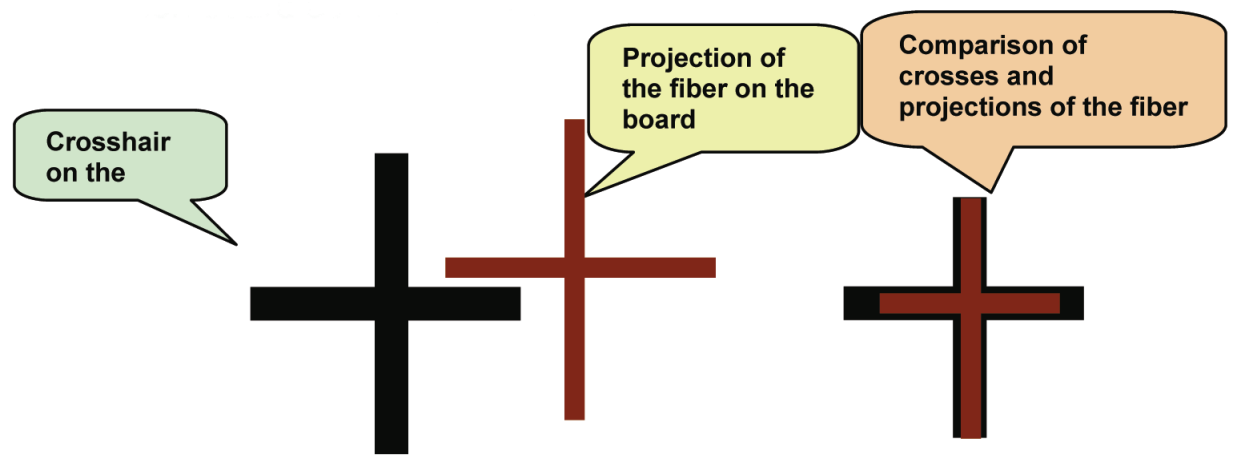

Figure 6 - The projection of the crosshairs on the board for rectification

Puc. 6 - Проекция перекрестия на бортовом баллистическом вычислителе

Слика 6 - Пројекција крста кончића на таблу за ректификацију

Figure 6 shows a projection of a $0.5 \mathrm{~mm}$ thick fiber. For the thickness of the fiber of $2 \mathrm{~mm}$, which is actually used in practice, the projection is

\footnotetext{
${ }^{7}$ The projection of the fiber on the rectification board is a $5.72 \mathrm{~mm}$ thick cross, viewed horizontally and vertically.
} 
$22.3 \mathrm{~mm}$. In this case, the center of the crosshair on the rectification board will practically not be seen, which is a potential mistake in the realization of the adjustment of axes parallelism.

For the rectification method at a distant point $(1000 \mathrm{~m})$, the thickness of the projection of the fiber is: $4785: 0.5=1000000: x$, where:

$$
x=\frac{1004785 \times 0.5}{4785} \Rightarrow x=105 \mathrm{~mm} .
$$

The projection of a $0.5 \mathrm{~mm}$ thick fiber at a distant chosen target located at a distance of $1000 \mathrm{~m}$ amounts to $105 \mathrm{~mm}$. The projection of the crosshair of the thickness of $0.5 \mathrm{~mm}$ at a distant target can be presented as in Figure 7.

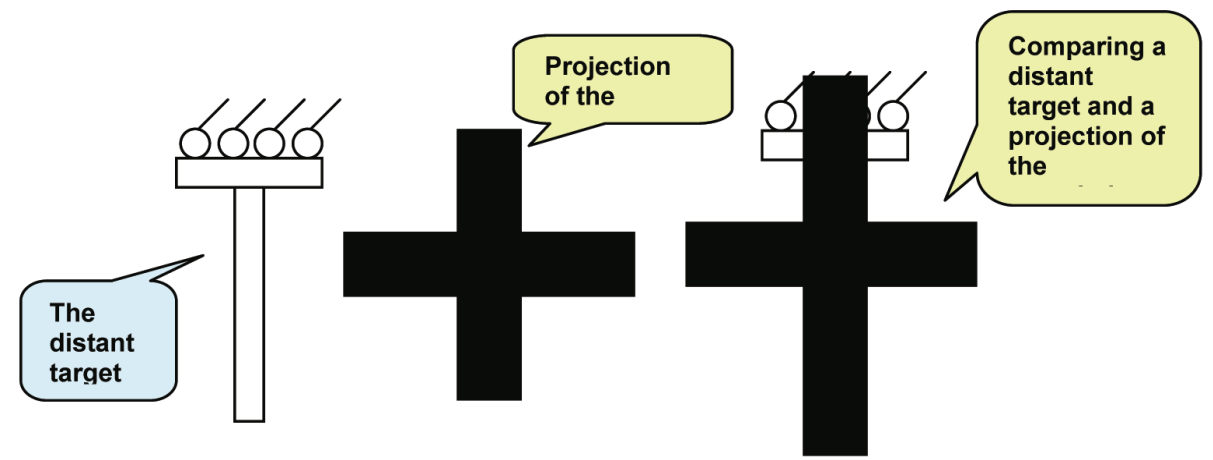

Figure 7 - Example of the projection of the crosshairs on a distant target Puc. 7 - Пример проекции перекрестия по дальней цели Слика 7 - Пример пројекције крста кончића на удаљени циљ

Figure 7 shows that, due to the projection of the fiber on a distant target, the distant target is practically hidden behind the projection, and the precise alignment of the axes is difficult (aiming with the bore axis). For the case of the thickness of the fiber of $2 \mathrm{~mm}$, the case is more pronounced as the projection of the fiber to the distant target is $420 \mathrm{~mm}$. Table 1 shows an overview of the fiber thickness and its projections for different rectification modes. 
Table 1 - Comparative overview of the fiber thickness and its projections on the target Таблица 1 - Сравнительный обзор толщины перекрестия и его проекции на цель Табела 1 - Упоредни приказ дебљине конца и његове пројекције на циљ

\begin{tabular}{|c|c|c|}
\hline & \multicolumn{2}{|c|}{ P R O J E C T I O N } \\
\hline $\begin{array}{c}\text { Thickness of } \\
\text { the fiber }\end{array}$ & A rectification board $-50 \mathrm{~m}$ & $\begin{array}{c}\text { The distant target - } \\
1000 \mathrm{~m}\end{array}$ \\
\hline $0.5 \mathrm{~mm}$ & $5.72 \mathrm{~mm}$ & $105 \mathrm{~mm}$ \\
\hline $2 \mathrm{~mm}$ & $22.3 \mathrm{~mm}$ & $420 \mathrm{~mm}$ \\
\hline
\end{tabular}

Table 1 clearly identifies a problem caused by the fiber thickness when aiming at a distant target or at a cross on the rectification board (aiming point). Namely, the projection of the fiber thickness makes it difficult to accurately aim the bore axis at a distant chosen target and the rectification board, because the projection is much bigger than the target, so the fiber projection hides the target, i.e. the target point. In this way, the accuracy of the method depends on the skill of the mechanic who performs aiming. Something more precise is aiming at the rectification board, because the thickness of the projection, in some cases, is slightly smaller than the thickness of the cross on the rectification board.

It is concluded that, according to technical documentation, the method of checking the parallelism of the axes of optical devices and the weapon bore is based on the unreliable method of bringing the axes to the distant target or the cross on the rectification board. Unreliability leads to the impossibility of precisely locating the selected distant target or the center of the cross on the rectification board, which leads to an error in determining the deviation of the individual axes from the imaginary parallel lines. The result is an unreliable way of rectification and insufficient accuracy of aiming devices, which directly affects the weapon precision during firing.

\section{Parallax}

Parallax is a shift of the target in relation to the crosshair when we move our head up or down as we look through the optics (Državni sekretarijat za narodnu odbranu, Tehnička uprava, 1969ab). Parallax occurs when the target does not fall on the same plane as the crosshair. A parallactic error occurs when aiming at long distances. The error in this case is a maximum of one thickness of a crosshair fiber or 0-00.5 thousandths. Since parallax occurs when aiming at targets at long distances, axes parallelism should be checked using a rectification board. 


\section{on the aiming accuracy}

Calculation of the axes deviation and impact

Based on the shown method for checking the parallelism of the axes of the panoramic sight and the weapon bore, according to technical documentation, the allowed deviation from the parallel is $0-00.5$ thousandths. Also, the allowed deviation of the optical sight axis from the barrel axis is $0-01.5$ thousandths. These allowed deviations are manifested in the aiming accuracy and the firing accuracy as seen in Figure 8 and the accompanying tables below.

From the given calculation, for the allowed deviation of the panorama axis from the barrel axis, at a distance of $16 \mathrm{~km}^{8}$, the aiming error amounts to $8 \mathrm{~m}$. Proportionally, by reducing the distance to the target, the error decreases (Table 2).

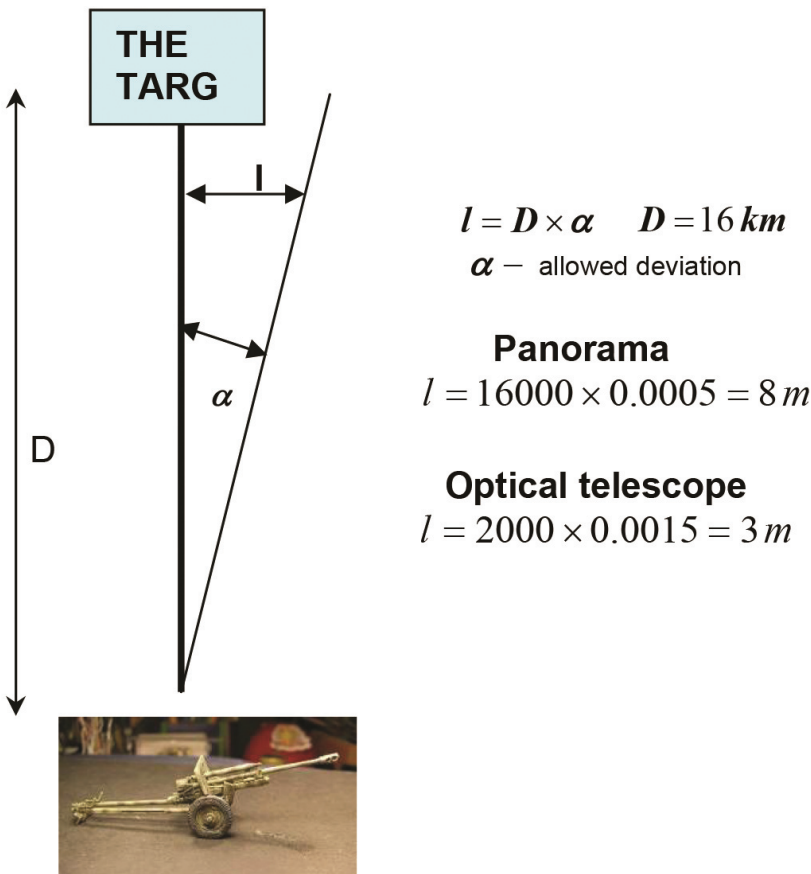

Figure 8-Example of the error calculation

Puc. 8 - Пример расчета погрешностей

Слика 8 - Пример прорачуна грешке

\footnotetext{
${ }^{8}$ Maximum shooting distance.
} 
Table 2 - Calculation of aiming errors according to the technical documentation panorama

Таблица 2 - Расчет погрешностей наведения по технической документации панорама

Табела 2 - Прорачун грешке нишањења према техничкој документацији панорама

\begin{tabular}{|c|c|c|}
\hline $\begin{array}{c}\text { Distance to } \\
\text { destination }(\mathrm{m})\end{array}$ & $\begin{array}{c}\text { Permissible deviation of } \\
\text { the panorama axis }\end{array}$ & $\begin{array}{c}\text { Aiming error in the } \\
\text { horizontal plane }(\mathrm{m})\end{array}$ \\
\hline 16000 & $0-00.5$ thousandths & 8 \\
\hline 8000 & $0-00.5$ thousandths & 2 \\
\hline 4000 & $0-00.5$ thousandths & 1 \\
\hline 2000 & $0-00.5$ thousandths & 0.5 \\
\hline 1000 & $0-00.5$ thousandths & \\
\hline
\end{tabular}

The calculation shows that for the permitted deviation of the axis of the optical sight from the barrel axis, at a distance of $2000 \mathrm{~m}$, the aiming error is $3 \mathrm{~m}$. Proportionally, by reducing the distance to the target, the error decreases (Table 3).

Table 3 - Calculation of aiming errors according to the technical documentation - telescope

Таблица 3 - Расчет погрешностей наведения по технической документации - телескоп

Табела 3 - Прорачун грешке нишањења према техничкој документацији - дурбин

\begin{tabular}{|c|c|c|}
\hline $\begin{array}{c}\text { Distance to } \\
\text { destination }(\mathrm{m})\end{array}$ & $\begin{array}{c}\text { Permissible deviation } \\
\text { of the OS axis }\end{array}$ & $\begin{array}{c}\text { Aiming error in the } \\
\text { horizontal plane }(\mathrm{m})\end{array}$ \\
\hline 2000 & $0-01.5$ thousandths & 3 \\
\hline 1000 & $0-01.5$ thousandths & 1.5 \\
\hline 500 & $0-01.5$ thousandths & 0.75 \\
\hline
\end{tabular}

The values of the aiming error in the horizontal plane displayed in Tables 2 and 3 represent the maximum deviation values according to the technical documentation, and in real conditions they are higher. This will be demonstrated by the application of the proposed method, where the obtained deviation values will be compared, based on which it can be concluded that in real conditions the deviation is higher.

The aiming error value in the vertical plane, based on the permissible deviation from the parallelism of the axes of the barrel and the aiming devices, decreases with the range increase. At the maximum range, the error is negligible. 


\section{Improving the rectification method using a laser pointer}

On the basis of the performed analysis of aiming errors in real conditions due to the thickness of the crosshair fiber, parallax and the axes parallelism checking skills during the application of the rectification method according to the technical documentation, measurement uncertainty occurs in the realization of the parallelism checking method. The application of the proposed rectification method based on the use of a laser pointer eliminates the influence of the human factor on the measurement procedure (aiming with the crosshair and parallax).

\section{Rectification method using a laser pointer}

The rectification procedure using a laser pointer is the following:

- laser pointer is held with the appropriate clamping tool,

- the clamping tool with the laser pointer is placed at the place of the $122 \mathrm{~mm}$ artillery primer,

- at the muzzle (gas brake), an appropriate circular mesh with a cross in the center is placed ${ }^{9}$ (Figure 9),

- rectification board is placed at a distance of $50 \mathrm{~m}$ from the muzzle,

- the laser pointer is activated and the clamp tool sets the laser beam to pass through the center of the circular mesh (through the cross),

- the circular mesh is removed from the gas brake and by gun laying, the laser beam is directed onto the right cross of the rectification board,

- the deviation of the optical devices from the corresponding crosses on the rectification board is measured and necessary adjustments are made.

In order to determine the real deviation of the optical axes on the basis of which the calculation of the aiming error will be carried out the proposed rectification method using a laser beam was applied to an overhauled $\mathrm{H}-122 \mathrm{~mm} \mathrm{D} 30$ artillery piece. Once again, the parallelism of all axes was checked using the method prescribed by the technical documentation $^{10}$ (Savezni sekretarijat za narodnu odbranu, Tehnička uprava, 1987), followed by the rectification based on the proposed method with a laser pointer.

\footnotetext{
${ }^{9}$ The circular mesh is of a round shape with a cross in the middle, as shown in Figure 9. The circular mesh is an integral part of the fire control tool of the computing department.

${ }^{10}$ Aiming at the rectification board was done using $2 \mathrm{~mm}$ thick fibers of the crosshair placed on the notches of the gas brake, for easier and more accurate aiming.
} 


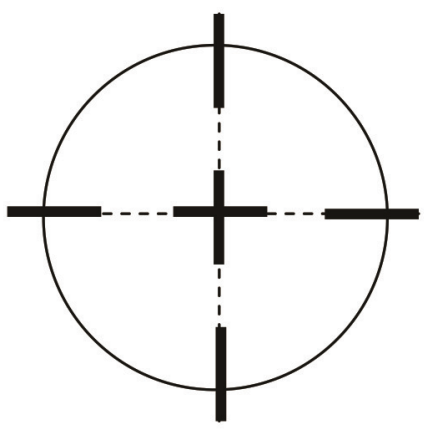

Figure 9 - Circular mesh

Puс. 9 - Изображение прицельной сетки

Слика 9 - Приказ кружне мреже

The laser beam was directed to the center of the circular mesh in the manner described above (Figure 10) and then to the corresponding cross on the rectification board. The following deviations of the panorama axis and the optical sight axis were obtained after the rectification was performed, in relation to the piece barrel axis:

- Panorama:

- 2 thousandths in the direction and

- 4 thousandths per elevation,

- Optical sight:

- 2 thousandths in the direction.

The checking and adjusting the optical axes of the panorama and the OS was repeated by the method prescribed in the technical documentation and once again the same results were obtained, i.e. the same deviations. As all the requirements of the measurement method were met, it is obvious that the technical documentation method has certain measurement uncertainty. Measurement uncertainty was a result of a lack of a method that depends on the subjective factor (the human eye), the crosshair fiber thickness and the parallax. Measurement uncertainty directly causes aiming error, and indirectly firing inaccuracy as shown in Tables 4 and 5. 


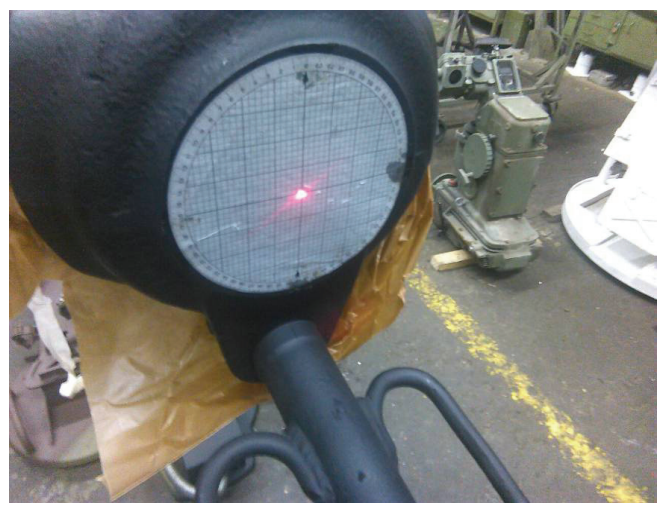

Figure 10 - Laser beam directed at the center of the circular mesh

Puc. 10 - Изображение лазерного целеуказателя, направленного в центр прицельной сетки

Слика 10 - Приказ ласерског снопа усмереног у центар кружне мреже

Aiming errors in artillery pieces, based on the obtained deviations in the parallelism of the axes of optical devices, are calculated in Tables 4 and 5.

Table 4 - Calculation of the aiming errors using the laser pointer - panorama

Таблица 4 - Расчет погрешностей наведения с помощью лазерного целеуказателя - панорама

Табела 4 - Прорачун грешке нишањења применом ласерског обележивача панорама ${ }^{11}$

\begin{tabular}{|c|r|c|}
\hline $\begin{array}{c}\text { Distance to destination } \\
(\mathrm{m})\end{array}$ & $\begin{array}{r}\text { Permissible deviation of } \\
\text { the panorama axis }\end{array}$ & $\begin{array}{c}\text { Aiming error in the } \\
\text { direction }(\mathrm{m})\end{array}$ \\
\hline 16000 & $0-00.5$ thousandths & 32 \\
\hline 8000 & $0-00.5$ thousandths & 16 \\
\hline 4000 & $0-00.5$ thousandths & 8 \\
\hline 2000 & $0-00.5$ thousandths & 4 \\
\hline 1000 & $0-00.5$ thousandths & 2 \\
\hline
\end{tabular}

The values obtained in Tables 4 and 5 represent real aiming errors that occur in the horizontal level with the $\mathrm{H}-122 \mathrm{~mm}$ D30 piece. As it can be seen, there are errors in the parallelism of the axes and they are higher than those prescribed by the technical documentation (Savezni sekretarijat za narodnu odbranu, Tehnička uprava, 1987), (Table 2 and 3).

${ }^{11}$ Aiming error leads to an error in firing elements determination and, consequently, to the deviation from the average impact point. 
Table 5 - Calculation of the aiming errors using the laser pointer - optical telescope Таблица 5 - Расчет погрешностей наведения с помощью лазерного целеуказателя - оптический телескоп

Табела 5 - Прорачун грешке нишањења применом ласерског обележивача оптички дурбин

\begin{tabular}{|c|c|c|}
\hline $\begin{array}{c}\text { Distance to destination } \\
(\mathrm{m})\end{array}$ & Permitted OS deviation & $\begin{array}{c}\text { Aiming error in the } \\
\text { direction }(\mathrm{m})\end{array}$ \\
\hline 2000 & $0-01.5$ thousandths & 4 \\
\hline 1000 & $0-01.5$ thousandths & 2 \\
\hline 500 & $0-01.5$ thousandths & 1 \\
\hline
\end{tabular}

The obtained results show that the human factor has a dominant influence on the quality of the method of adjusting the optical axes. The only way to achieve quality results and a minimal deviation of the parallelism of the optical axes from the bore axis is to exclude the human factor and improve the rectification method.

This is achieved by the proposed rectification method using a laser pointer, which is based on the fact that the laser beam propagates in a straight line to the aiming point on the rectification board, thereby contributing to the method accuracy. This method eliminates the unreliability of aiming with crosshairs and the parallax of the human eye, since the influence of a man from the critical part of the measurement method is eliminated. This reduces the method measurement uncertainty. In addition, the proposed method is implemented by one artillery crew member, unlike the previous one where two members were necessary. A reduced number of staff affects the reduction of norms, which directly increases capacity.

\section{Description of the proposed method}

The proposed rectification method, i.e. the verification of the parallelism of the optical axes with the bore axis, uses a laser beam of a laser pointer in order to increase the accuracy of aiming at the cross on the rectification board. After aiming with the laser beam, the deviations of the optical axes are checked and corrected.

The rectification method using a laser pointer is given previously while the subsequent corrections on optical devices are described and implemented according to the method given in the technical documentation (Savezni sekretarijat za narodnu odbranu, Tehnička uprava, 1987).

The clamping tool used to hold the laser pointer is shown in Figure 11. 


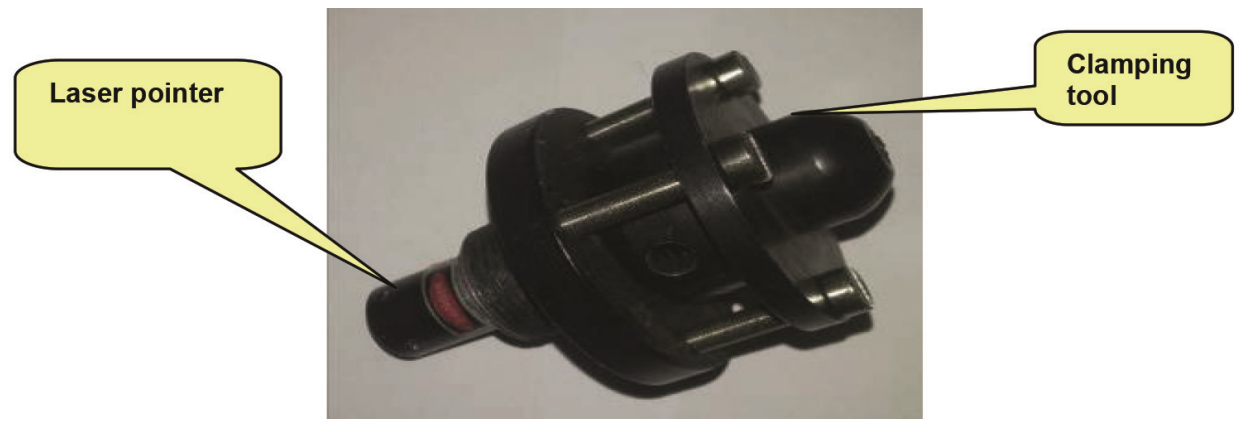

Figure 11 - Clamping tool with a mounted laser pointer

Pис. 11 - Изображение зажимных деталей с лазерным целеуказателем

Слика 11 - Приказ стезног алата са постављеним ласерским обележивачем

Figure 12 shows the components of the clamping tool. The components allow the mounting and fixing of the laser pointer, as well as its shifting along the $X$ and $Y$ axes when directing the laser beam.

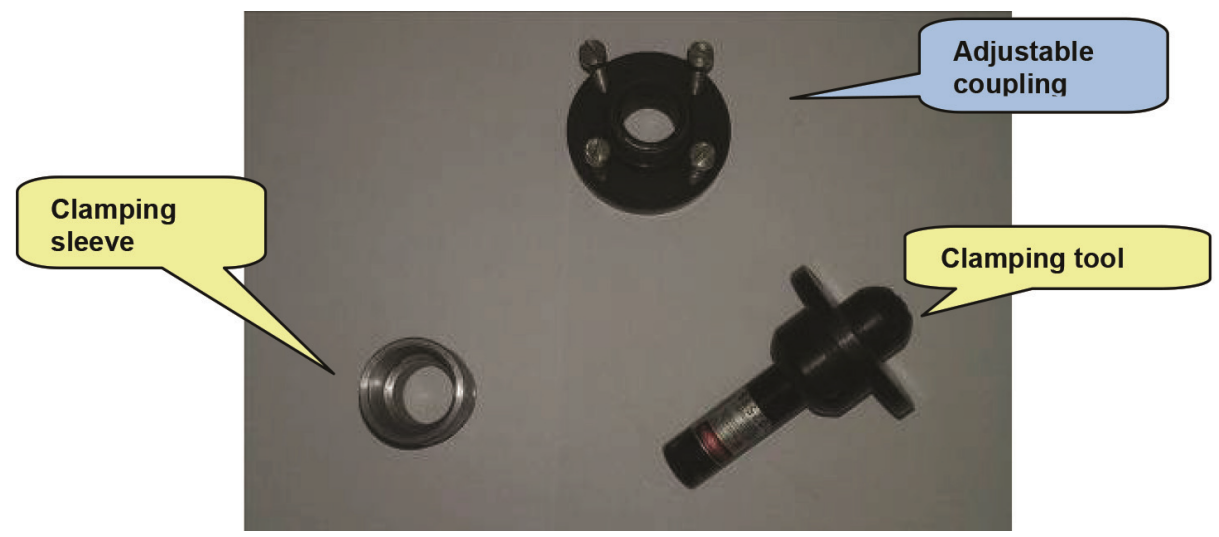

Figure 12 - Parts of the clamping tool for the laser pointer Puc. 12 - Зажимные детали лазерного целеуказателя Слика 12 - Делови стезног алата ласерског обележивача

After placing the laser pointer in the clamping tool, the clamping tool is fastened to the technological sleeve (Figure 13). In the center of the sleeve, in the opening in which the primer is placed, there is a thread by means of which the clamping tool for the laser pointer is fixed, which allows the laser beam to overlap the bore axis. An appropriate opening is made on the sleeve to check the direction of the laser beam. 


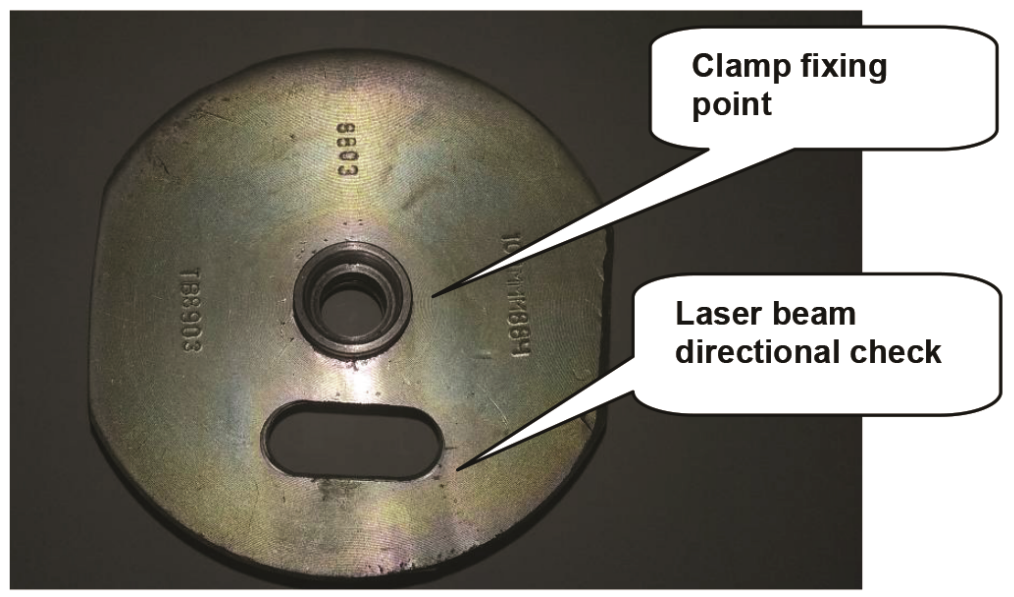

Figure 13 - Technological sleeve

Pис. 13 - Изображение технологической гильзы Слика 13 - Приказ технолошке чауре

Alignment is performed by adjusting the clamping tool on the $X$ and $Y$ axes (with four screws on the adaptive coupling, two screws for each axis) so that the laser beam is directed to the center of the circular mesh located on the gas brake on the muzzle. The edge of the technological sleeve is removed from the place where the extruders come in so that breech is open and accessible.

Figure 14 shows a technological sleeve with a mounted clamping tool and a laser pointer.

After directing the laser beam into the center of the circular mesh, it is considered that the laser beam matches the imaginary axis of the weapon bore. The circular mesh is removed from the gas brake and by the rotating the barrel in direction and elevation, the laser beam is directed to the lower right-hand cross of the rectification board placed at a distance of $50 \mathrm{~m}$ from the muzzle (Fig. 15). In this way, the laser beam represents a prolonged bore axis towards the aiming point of the rectification board.

After bringing the laser beam to the aiming point of the rectification board, it is possible to read the deviations of the optical axes of the panorama and the OS from the corresponding aiming points (crosses) on the rectification board and to correct them. The correction is done in such a way that they are set up to have their optical axis at the appropriate aiming points of the rectification board and adjusting the scale according to TU-I. The parallelism of all three axes is thus achieved, which ensures the accuracy of the optical devices and weapon precision when shooting at a remote target. 


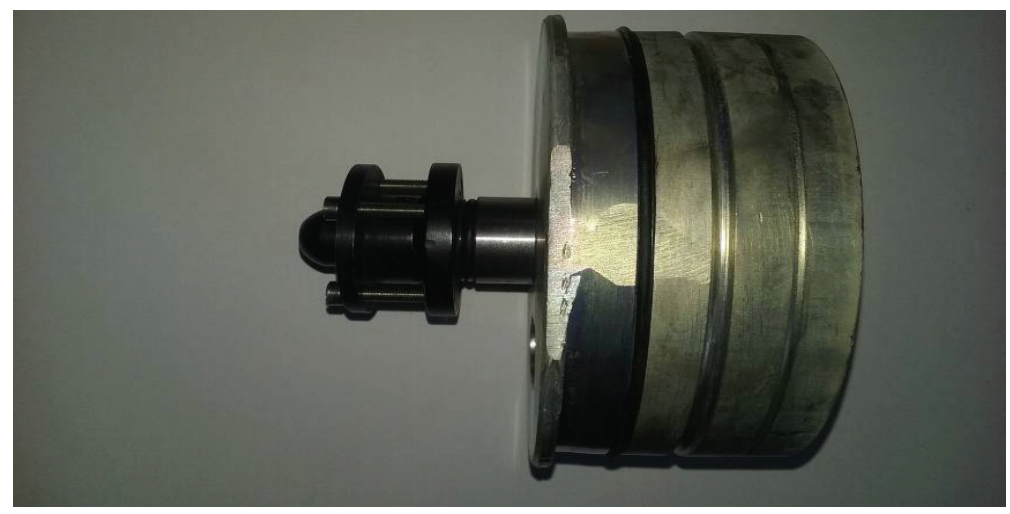

Figure 14 - Clamping tool with a laser pointer on the technological sleeve Puc. 14 - Зажимной инструмент с лазерным целеуказателем на технологической гильзе Слика 14 - Стезни алат са ласерским обележивачем на технолошкој чаури

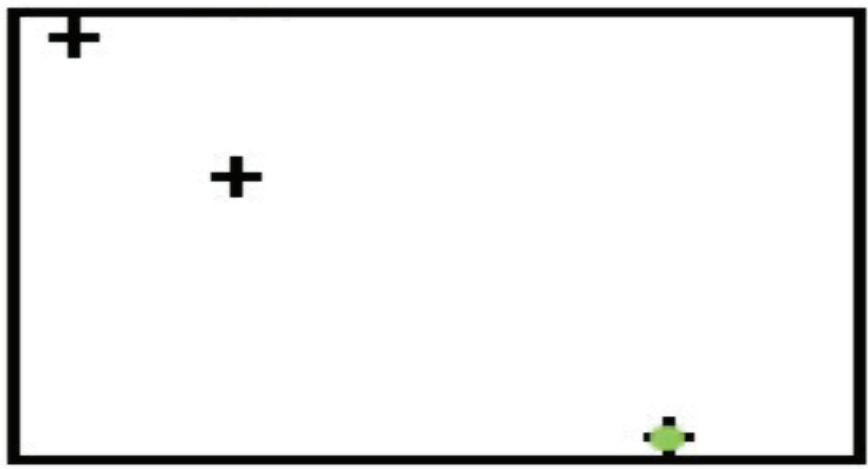

Figure 15 - Layout of the rectification board with the laser beam at the aiming point of the weapon barrel axis

Puс. 15 - Изображение на бортовом баллистическом вычислителе с лазерным указателем в точке прицела ствола орудия

Слика 15 - Изглед табле за ректификацију са ласерским снопом на нишанској тачки осе цеви оруђа

The proposed rectification method with a laser pointer can be applied to any artillery piece or weapon in day and night conditions, provided there is an appropriate technology sleeve, the clamping tool and the rectification board. 


\section{Structure of tools and working tools with economic indicators}

Table 6 lists the data on the necessary tools and means for implementing the method of rectification with the laser pointer, as well as the necessary funds and their sources.

Table 6 - Data on the necessary resources and tools for the method application Таблица 6- Сведения о необходимых ресурсах и инструментах для применения данных методов

Табела 6 - Подаци о потребним средствима и алату за примену методе

\begin{tabular}{|c|c|c|c|c|}
\hline$r / b$ & $\begin{array}{c}\text { Name of tools and } \\
\text { means of work }\end{array}$ & Quantity & Source & $\begin{array}{l}\text { Approximate } \\
\text { price (RSD) }\end{array}$ \\
\hline 1 & Laser pointer * & 1 & $\begin{array}{c}\text { Procurement from } \\
\text { the market }\end{array}$ & 1200,00 \\
\hline 2 & Technological sleeve & 1 & $\begin{array}{c}\text { The Army } \\
\text { of Serbia } \\
\text { (Finalisation } \\
\text { in the Institute) }\end{array}$ & - \\
\hline 3 & $\begin{array}{l}\text { Clamping tool for a } \\
\text { laser pointer }\end{array}$ & 1 & $\begin{array}{l}\text { Production at the } \\
\text { Institute }\end{array}$ & 800,00 \\
\hline 4 & Circular mesh & 1 & The Army of Serbia & - \\
\hline 5 & A rectification board & 1 & The Army of Serbia & - \\
\hline & IN TOTAL: & $\begin{array}{c}1 \\
\text { set }\end{array}$ & TOI Čačak & 2000,00 \\
\hline
\end{tabular}

The data listed in Table 6 refers to the tools and means of work for one type of artillery pieces, except for those marked with an asterisk that can be used for all types of artillery weapons. The product in position 2, a technological sleeve, needs to be upgraded in the Institute, by making a hole for fixing the clamping tool to carry the laser pointer (Figure 11). The tool in position 3 is made in the Institute.

The total cost per one set, for one piece type, is about 2,000 RSD.

\section{Conclusion}

The aim of the research was to improve the existing method of rectification of the axes of optical devices in order to achieve better precision of shooting with the current weapons. The goal is achieved by applying a new rectification method based on the use of laser pointers.

The description of the method of rectification of optical devices based on the use of the laser pointer and its application in the process of general 
overhaul of the $\mathrm{H}-122 \mathrm{~mm}$ howitzer D30 at the Technical Overhauling Institute Čačak, as well as the obtained results by measurement, show the following advantages of the proposed method:

- the subjective factor in the realization of the method is eliminated,

- it provides accurate data on the deviation of the optical axes, allowing their correction and harmonization,

- the aiming accuracy and the firing accuracy are achieved,

- measurement uncertainty of the rectification method is reduced to a minimum, which ensures the reliability of the rectification method,

- much shorter technological time required to check the alignment of the optical axes and the weapon barrel axis,

- checking the alignment of the optical axes and the barrel axis is carried out by one person, which reduces the necessary technological capacity envisaged for these procedures,

- a uniform rectification quality is achieved in each repeatition of the axes alignment check,

- rectification is solely done using a rectification board located at a distance of $50 \mathrm{~m}$ and in this way the method does not depend on climatic conditions, the time of the day or night, and the possibilities of determining a distant target by which the TU-I method is implemented. Also, since rectification is done at small distances, the parallax error is avoided.

Further research in this area can be directed to the application of the proposed method of rectification with a laser pointer to all artillery pieces up to $155 \mathrm{~mm}$ caliber, including the M84 tank. Also, research can be applied to weapons using a periscope for rectification.

\section{References}

- Državni sekretarijat za narodnu odbranu, Tehnička uprava, Beograd, 1969a. Državni sekretarijat za narodnu odbranu, Tehnička uprava, Beograd, Uputstvo za remont optičkih instrumenata, 6206, TS-V, 721. Split: Vojna štamparija (in Serbian).

- Državni sekretarijat za narodnu odbranu, Tehnička uprava, 1969b. Državni sekretarijat za narodnu odbranu, Tehnička uprava, Poznavanje i tekuće održavanje optičkih instrumenata. Vojna štamparija Beograd (in Serbian).

Kalezić, M., 2010. Projektovanje artiljerijskih sistema. Beograd: Narodna biblioteka Srbije. ISBN 978-86-912671-0-0, COBISS.SR-ID 175025932 (in Serbian).

- Savezni sekretarijat za narodnu odbranu, Tehnička uprava, 1987. Haubica 122mmD-30J, Opis, rukovanje, osnovno i tehničko održavanje. Beograd: Vojna štamparija. UDK 623.421.3.004 (in Serbian). 
СОВЕРШЕНСТВОВАНИЕ МЕТОДОВ СПРЯМЛЕНИЯ

НАВЕДЕНИЯ ОПТИЧЕСКИХ УСТРОЙСТВ

С ПРИМЕНЕНИЕМ ЛАЗЕРНОГО ЦЕЛЕУКАЗАТЕЛЯ

Войкан М. Радонич, Бранко В. Ресимич

Вооруженные силы Республики Сербия, Сухопутные войска,

Техническое бюро ремонта Чачак, г.Чачак, Республика Сербия

ОБЛАСТЬ: логистика, техническое обслуживание

и технические ресурсы

ВИД СТАТЬИ: профессиональная статья

ЯЗЫК СТАТЬИ: английский

Резюме:

Данная статья основана на наблюдениях за выполнением предписанных действий, осуществляемых на артиллерийском орудии во время содержания и сервиса непосредственно перед выполнением боевых стрельб. Согласованность параллельности осей оптических приборов и оси ствола артиллерийского орудия напрямую влияет на точность прицела и стрельбы. С помощью нового метода согласования параллельности осей, основанного на применении лазерного целеуказателя, отклонения от параллельности осей сведены к минимуму, тем самым повышая точность стрельбы артиллерийского орудия. Разработан быстрый, легкий и надежный метод сверки параллельности осей, согласованных с осью ствола артиллерийского орудия.

Ключевые слова: спрямление наведения, оптические оси, лазерный целеуказатель.

ПОБОЉШАҢЕ МЕТОДЕ РЕКТИФИКАЦИЈЕ ОПТИЧКИХ СПРАВА ПРИМЕНОМ ЛАСЕРСКОГ ОБЕЛЕЖИВАЧА

Војкан М. Радоњић, Бранко В. Ресимић

Војска Србије, Копнена војска, Технички ремонтни завод Чачак, Чачак, Република Србија

ОБЛАСТ: логистика, одржавање техничких средстава ВРСТА ЧЛАНКА: стручни чланак

ЈЕЗИК ЧЛАНКА: енгЛескИ

\section{Сажетак:}

Рад је настао на основу сагледавања прописаних радњи, које се реализују на артиљеријском средству, у току одржавања средства и непосредно пре извођења бојевих гађања овим средством. Усаглашавање паралелности оса оптичких справа и осе цеви артиљеријског средства директно утиче на прецизност гађања средством. 
Новом методом усаглашавања паралелности оса, заснованој на коришћењу ласерског обележивача, одступање паралелности оса своди се на минимум, чиме се побољшава прецизност гађања артиљеријским средством. Такође, омогућава се поуздана, лакша и брза провера паралелности оса и њено усаглашавање са осом цеви средства.

Кључне речи: ректифрикација, оптичке осе, ласерски обележивач.

Датум пријема чланка / Дата получения работы / Paper received on: 15.02.2017. Датум достављања исправки рукописа / Дата получения исправленной версии работы / Manuscript corrections submitted on: 28.06.2017.

Датум коначног прихватања чланка за објављивање / Дата окончательного согласования работы / Paper accepted for publishing on: 30.06.2017.

(c) 2017 Аутори. Објавио Војнотехнички гласник / Vojnotehnički glasnik / Military Technical Courier (www.vtg.mod.gov.rs, втг.мо.упр.срб). Ово је чланак отвореног приступа и дистрибуира се у складу са Creative Commons licencom (http://creativecommons.org/licenses/by/3.0/rs/).

( 2017 Авторы. Опубликовано в «Военно-технический вестник / Vojnotehnički glasnik / Military Technical Courier» (www.vtg.mod.gov.rs, втг.мо.упр.срб). Данная статья в открытом доступе и распространяется в соответствии с лицензией «Creative Commons» (http://creativecommons.org/licenses/by/3.0/rs/).

(C) 2017 The Authors. Published by Vojnotehnički glasnik / Military Technical Courier (www.vtg.mod.gov.rs, втг.мо.упр.срб). This article is an open access article distributed under the terms and conditions of the Creative Commons Attribution license (http://creativecommons.org/licenses/by/3.0/rs/). 